\title{
FLEXICURITY - CHALLENGE TO IMPROVE CZECH LABOUR MARKET
}

Zuzana Potužáková

Metropolitan University Prague, Department of Economics, Dubečská 900/10, 100 31, Prague (potuzakova@mup.cz)

\begin{abstract}
Flexicurity reflects the current basic trend of the EU in guaranteeing high employment levels and attainability of national fiscal systems. It was introduced in Denmark in the 1990s and significantly helped reduce unemployment levels. The Czech labour market, despite the transformation process, has still space for further improvement, especially in the time of economic slow-down. The best way is to try to apply elements and components which have been already successfully implemented in the other EU Member States. The aim of the paper is (based on the statistical indicators and official documents concerning labour markets topic) to describe the basic function of the model and find the components of the flexicurity model which could be used also in the Czech Republic and change labour market operation.
\end{abstract}

Key words: flexicurity, EU, Czech Republic, labour market

JEL Classification: J01, J10, J24

DOI: $10.2478 / \mathrm{v} 10135-009-0005-4$

Národohospodářský obzor - Review of Economic Perspectives ISSN 1804-1663 (Online), ISSN 1213-2446 (Print)

http://nho.econ.muni.cz/en

(C) Masarykova univerzita 


\section{FLEXICURITY - CHALLENGE TO IMPROVE CZECH LABOUR MARKET ${ }^{1}$}

\section{Zuzana Potužáková}

\section{Introduction}

In the recent two decades, the Czech labour market has been deeply reformed due to the political and economic changes. In spite of these reform steps, there is a space for the future improvement, especially in the time of the global economic slow-down. The paper is divided into two parts. In the first one we explain the reasons why flexicurity got so popular and what are the potential threats in implementing it into other economies. The second part deals with those elements of the flexicurity model (the so called golden triangle) which could be implemented into the Czech labour market and improve its functioning. In this part, we will mention the flexicurity elements which are already used as within the active labour market policy (ALMP).

\section{Fexicurity and its elements}

Flexicurity, composed from the words flexibility and security, reflects current basic trend in guaranteeing high employment levels and sustainability of national fiscal systems in the welfare states. The fundamental idea behind the concept of flexicurity is that flexibility and security are not contradictory to one another, but in many situations can be mutually supportive. As a concept, flexicurity was created in the Netherlands in the mid-1990s, based on a number of specific conditions. The goal of the Dutch flexicurity legislation was to correct an imbalance between an inflexible labour market for core workers and an insecure labour market situation for the contingency workforce.

In Denmark this concept was used in the broader way in the 1990s and helped to reduce the unemployment levels significantly. The basic idea of this model comes from the so called Golden triangle and focuses on combination of adaptability to a changing international environment and a solidaristic welfare system. It combines a liberal and flexible labour market with low barriers to (re)enter/leave and generous welfare system. The high degree of mobility from employer to employer is linked to the low level of employment protection in the Danish labour market. Thanks to the generous unemployment support, Danes are not afraid of changing jobs often. Based on this we speak about high numerical flexibility - number of people changing the job is therefore substantially higher than in the EU. Denmark has the highest figures in the percentage of employed which are each year affected by unemployment and receive unemployment benefits or social assistance (around $20 \%$ ) within the EU. But the majority of these unemployed persons manages to find their own way back into a new job.

The third part consists of active labour markets policy (ALMP) which enables to prequalify those who do not enter the labour market within a short period. There are two important effects in this connection. On the one hand, as a result of the active measures, the participants in various programmes (e.g. job training and education) are upgraded

1 The paper was prepared within the project of the Czech Science Foundation GAČR 402/07/0521, Internal Market and its Effects within Visedgrad 4. 
and thus improve their chances of getting a job (qualification effect). On the other hand, the measures can have a motivational effect in that unemployed persons, who are approaching the time when they are due for activation, may intensify their search for ordinary jobs, in case they consider activation a negative prospect. ${ }^{1}$ The golden triangle of flexicurity is illustrated in the scheme No. 1.

Scheme No. 1 - Golden triangle of flexicurity

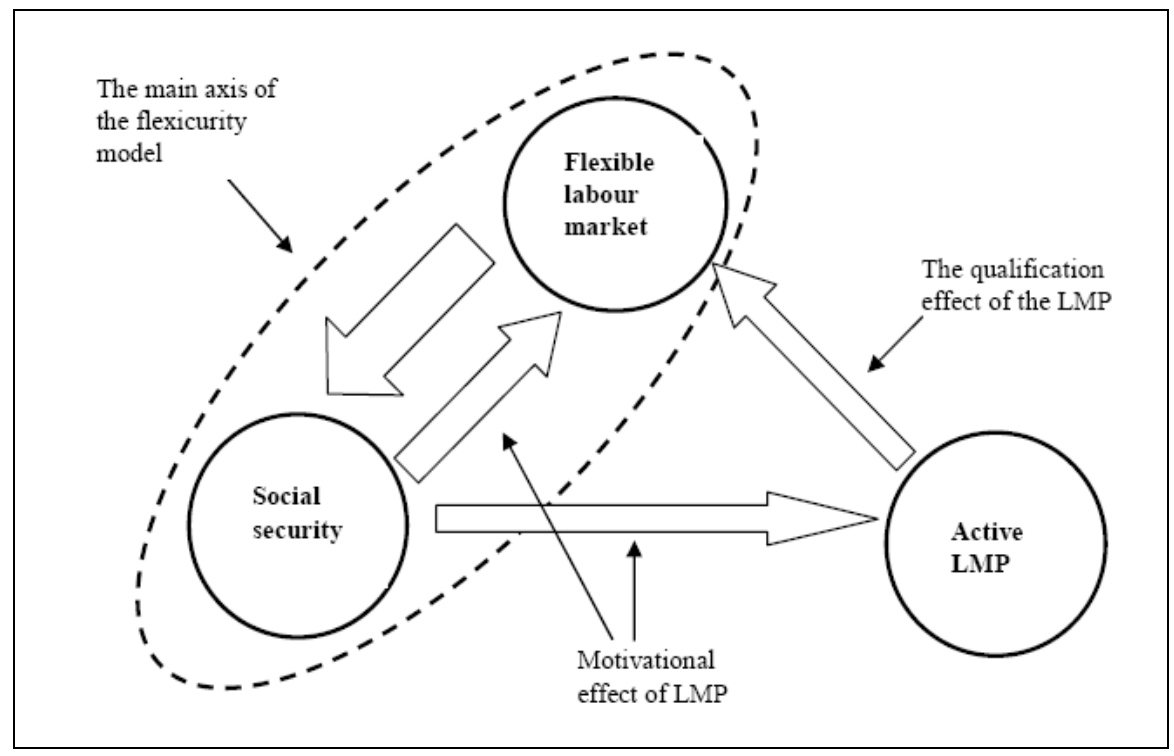

Source: Madsen (2006), p. 8

Danish employment system is defined as a 'hybrid' one. It includes a very liberal feature - non-restrictive employment protection legislation typical for Anglo-Saxon labour markets and generous welfare regime of social security usual in Scandinavian countries. The system is generally accepted in Denmark and is based on public consensus. Flexicurity stresses the potential for win-win-outcomes in situations which are traditionally conceived as characterised by conflicting interests. ${ }^{2}$ During the so called Danish job miracle the unemployment rate was reduced by $50 \%$ from $10 \%$ in 1993 to $5 \%$ in $2002 .^{3}$ This is without any doubt a very good result and since the end of the 1990s, the flexicurity model became one of the "export articles" from Denmark and other EU states started to implement this model into their employment systems.

The EU implemented this concept into the Lisbon Strategy in 2006. Lisabon strategy, started in 2000 on European council in Lisbon, ${ }^{4}$ aimed on improving of the EU competitiveness within the world economy. In 2004 the Strategy was primarily focused on economic growth. Growth could be created only in case there are enough jobs with a high productivity. Otherwise the EU states would not be able to guarantee current

\footnotetext{
${ }^{1}$ Madsen (2006), p.7.

${ }^{2}$ Madsen (2006), p.3.

${ }^{3}$ Madsen (2002), p. 2.

${ }^{4} \mathrm{http} / / /$ ec.europa.eu/growthandjobs/european-councils/index_en.htm [15.8.2009]. 
welfare standards in the future. Based on these circumstances, the flexicurity concept was strongly welcomed within the EU.

In 2006 , the Spring European council ${ }^{1}$ stressed the need to develop more systematically in the National Reform Programmes comprehensive policy strategies to improve the adaptability of workers and enterprises. It noted that the Commission, together with Member States and social partners, will explore the development of a set of common principles on flexicurity. ${ }^{2}$ As the Commission further noted, "Common principles of flexicurity will provide Member States and the European Union with a common understanding of flexicurity and the challenges it aims to address. They will strongly underline the involvement of the EU in securing Europe's social and economic future". ${ }^{3}$ Another paper concerning this topic was published in 2007 by the DG Employment. ${ }^{4}$ This paper already highlights some good example practices already applied in the Member States.

The EU, which is nowadays facing many external and internal challenges (in EU language this means threats), is doing its best to mobilize as much of human resources as possible and adapt the labour market for the disadvantaged groups at the margins (e.g. older workers, disabled, youth, etc.). All these steps try to aim on the high employment. High employment rates have two different contributions. The first contribution is the social one. In case of high employment rates, the "negative social behaviour" is reduced. The other gain is economical; the more people are employed, the more people contribute to the budget and less resources for unemployment/social benefits are required. This helps to secure the welfare systems.

Flexicurity reflects also another feature of the today's society, that means to keep economically active the people employed in the jobs with low requirements on labour force. Due to changing employment structures the requirements on labour force are rising. In the past, most of people worked in agriculture sector with plenty of jobs demanding limited skills. Due to the industrialization and later the tertialisation process more skills were needed to manage the jobs. The jobs with low requirements on labour force are disappearing from Europe.

Today, most of the EU labour force is employed in service sector. In 2007, almost $70 \%$ jobs belonged into tertiary sector in EU-15 and about $60 \%$ in EU-12. ${ }^{5}$ In general, we can consider European labour markets for societies where the computer and language skills are broadly expected. The so called "knowledge society" got leitmotif of many Commission's papers of the recent period. Despite the rising requirements on human resources, their abilities remain on the same level. From the social and even economical point of view, for the state it is less expensive to pre-qualify workers, create jobs for them and keep them economically active.

\footnotetext{
${ }^{1}$ http://ec.europa.eu/growthandjobs/european-councils/index_en.htm [15.8.2009].

${ }^{2} \mathrm{EC}(2007 \mathrm{a})$, p. 4.

${ }^{3}$ Ibid.

${ }^{4}$ EC (2007c) Towards Common Principles of Flexicurity: More and better Jobs through Flexibility and Security.

${ }^{5}$ http://www.czso.cz/csu/2008edicniplan.nsf/kapitola/1607-08-2008_(vybrane_udaje)-3 [18.8.2009].
} 
In 2006, the EU defined the so called pathways to improve the functioning of the labour markets: ${ }^{1}$

- Pathway 1: Reduce asymmetries between non-standard and standard employment by integrating non-standard contracts fully into labour law, collective agreements, social security and life-long learning, and consider making employment in standard contracts more attractive to firms,

- Pathway 2: Enhance companies' and workers' adaptability by developing and strengthening transition security,

- Pathway 3: Address opportunity and skills gaps among the workforce by broadening and deepening investments in skills,

- Pathway 4: Enhance employment opportunities for benefit recipients, prevent longterm welfare dependence, regularise informal work and build up more institutional capacity for change.

The EU pathways in general correspond with the elements of the Danish golden triangle. First two pathways cope with the active labour market measures. The third and forth one includes ALMP elements declaring the tendency to prefer active labour market policy to the passive one. The first element, flexible labour market, is described to the greatest detail; general welfare system is left completely unnoticed. That signalizes where weaknesses of most European labour markets are.

All the measures of the model and the model as a whole make a very positive impression. In Denmark, the unemployment rate was substantially reduced, as well as the long-term unemployment. Subsequently, the employment rate grew to the one of the highest employment rates in the $\mathrm{EU}^{2}$, reaching almost $80 \%$ in 2008. Anyway, there are some aspects which enable this concept in Denmark to function and which are typical for this economy. In case the flexicurity is implemented into any other economy, the concept may not have the same positive effect.

Low employment protection strictness for various groups of employers (regular workers, temporary workers) is one of the particularities of the Danish labour market. This strictness measured by Employment Protection Legislation (EPL) index was constructed by OECD. EPL indicates how easy or complicated hiring and firing the workers in a particular economy is. The figure can oscillate from 0 (no protection) to 6 (maximum protection). That means the higher the figure is, the higher is the employment protection. Table No. 1 records the EPL index for all the EU Member States who are OECD members as well. As we can see, the Danish economy has lower employment protection according to the European standards (overall strictness in Denmark is 1.8). The barriers are low for all the employers groups with small differences in employment protection regime. In the EU, the lower value of the EPL was recorded only in the UK and Ireland. The highest protection of employers was in the Southern Europe (Portugal, Spain, and Greece).

Should other Member States implement the flexicurity model into their economies, they would have to reform their labour codes, reduce their employment protection and

\footnotetext{
${ }^{1} \mathrm{EC}(2007 \mathrm{a})$, p. 5.

2 http://epp.eurostat.ec.europa.eu/portal/page/portal/structural_indicators/indicators/employment [16.8.2009].
} 
differences between various groups of workers on the labour market. This measure includes also the Pathway 1. In this case the problem dwells rather in realization and reform of national labour codes, although the Danish case shows that the lower employment protection is not harmful for employees.

Despite a high fraction of workers being affected by unemployment each year (around 20 percent), majority of these unemployed persons manages to find their own way back into a new job. As an indication, the long-term unemployment as a percentage of total unemployment (6+ months, 12+ months) in 2004 was $45 \%$ and $22.6 \%$ in Denmark, compared to $60.4 \%$ and $42.4 \%$ in EU-15. ${ }^{1}$ Those who become long-term unemployed end up in the target group for the active labour market policy, which - ideally - helps them find job again. ${ }^{2}$

Table No. 1. EPL in 2008

\begin{tabular}{|l|c|c|c|c|}
\hline Type of contract & Regular & Temporary & \multicolumn{2}{|c|}{ Overal EPL strictness } \\
\hline State/Year & 2008 & 2008 & 1998 & 2008 \\
\hline Austria & 2,4 & 1,5 & 2,4 & 2,2 \\
\hline Belgium & 1,7 & 2,6 & 2,5 & 2,5 \\
\hline Czech Republic & 3,0 & 0,9 & 1,9 & 2,0 \\
\hline Denmark & 1,6 & 1,4 & 1,9 & 1,8 \\
\hline Finland & 2,2 & 1,8 & 2,2 & 2,0 \\
\hline France & 2,5 & 3,6 & 2,8 & 2,9 \\
\hline Germany & 3,0 & 1,2 & 2,6 & 2,4 \\
\hline Greece & 2,3 & 3,1 & 3,5 & 2,8 \\
\hline Hungary & 1,9 & 1,4 & 1,5 & 1,7 \\
\hline Ireland & 1,6 & 0,6 & 1,2 & 1,3 \\
\hline Italy & 1,8 & 2,0 & 3,1 & 2,4 \\
\hline Netherlands & 2,7 & 1,2 & 2,8 & 2,1 \\
\hline Poland & 2,1 & 1,8 & 1,9 & 2,2 \\
\hline Portugal & 4,2 & 2,1 & 3,5 & 2,9 \\
\hline Slovak Republic & 2,5 & 0,4 & 2,2 & 1,8 \\
\hline Spain & 2,5 & 3,5 & 3,0 & 3,9 \\
\hline Sweden & 2,9 & 0,9 & 2,5 & 2,2 \\
\hline United Kingdom & 1,1 & 0,4 & 1,0 & 1,1 \\
\hline OECD total & 2,1 & 1,8 & 2,2 & 2,1 \\
\hline Source: OECD & & & & \\
\hline
\end{tabular}

Source: $O E C D$,

http://www.oecd.org/document/22/0,3343,en_2649_39023495_43221014_1_1_1_1,00.html\#epl

\footnotetext{
${ }^{1}$ The fact that Denmark has the highest expenditures on disability within the EU is the ,dark side 'of the low long-term unemployment rate. In 2006, $14.9 \%$ of the total social benefits (or $4.2 \%$ of the GDP) were aimed on disability, compared with $7.5 \%$ in the EU-27 (1.9\% of the GDP), according to the Eurostat. To sum up, instead of high unemployment benefits, there are high disability costs in Denmark. Disabled people do not belong into the group of economically active, which makes the long-term unemployment rates impressively low.

${ }^{2}$ Madsen (2007), p. 15.
} 
Another specific is the difference in distribution of responsibilities of the social partners, namely the unions. In Denmark, the social insurance is based on the so called Ghent system. In this system, the unions were historically responsible for payment of unemployment benefits. That explains the huge fraction of trade union membership in Denmark (about $80 \%$ of workers) and also in other Scandinavian countries (Finland, Sweden) where this system more or less exists. Today in Denmark, there are 31 state recognised unemployment insurance funds. Most of the unemployment insurance funds are affiliated with one or more trade unions. Workers will conceive the membership of the trade union and the affiliated unemployment insurance fund as a package. ${ }^{1}$ The members of the unemployment insurance funds will therefore only be obliged to pay a fixed membership contribution, independent of the actual level of unemployment.

The state has been taking over the responsibility for financing the extra costs of unemployment benefits that were caused by increases in unemployment (the principle of public financing "at the margin") since 1969. The government's share consists of 50$80 \%$ of the total unemployment benefits costs, depending on number of the unemployed. As we can see, the unions played quite an important role in distributing unemployment benefits. They were paid from their own funds (today insurance funds). This means that the general interest of the unions was to reduce the number of the unemployed because the rising number of unemployed meant the rising costs for their insurance funds. Within the Ghent system, the unions have a strong position in barraging collective agreements but their responsibility was traditionally higher due to the obligation of distribution of unemployment benefits.

Finally, Denmark invests considerable amounts of money into activation policies and continuously adapts of the economy to keep the pace for the future competitiveness. In 2007, according to the OECD, Denmark invested about $1.3 \%$ of GDP into active labour market policy (ALPM) - the highest rate in the EU, and $1.5 \%$ GDP into passive measures. The OECD average is $0.6 \%$ GDP for the ALPM and $0.8 \%$ for the passive one. ${ }^{2}$ According to the same database, the Czech Republic and Slovakia invested only $0.2 \%$ GDP into ALMP, which is the lowest fraction in OECD.

Furthermore, in 2006 Denmark launched the Globalisation Fund. ${ }^{3}$ Until 2012, almost 40 billion DKK (about 5.2 billion EUR) will be provided for education, research and entrepreneurship. Such a project is rare within the EU and enables to Denmark to gain educated and skilled labour force. In the scheme No. 2 we can see how the resources of the fund should be distributed. All these measures correspond with general recommendation of the Commission's papers concerning the competitiveness topic. ${ }^{4}$

\footnotetext{
${ }^{1}$ Ibid, p. 11.

2 http://www.oecd.org/document/22/0,3343,en_2649_39023495_43221014_1_1_1_1,00.html\#almp [17.8.2009].

${ }^{3}$ National Reform Programme 2007 Denmark, p. 19.

${ }^{4}$ E.g. High Level Group report Facing the Challenge or Integrated Guidelines for Growth and Jobs (2008-10) available on: http://ec.europa.eu/growthandjobs/pdf/european-dimension-200712annual-progress-report/200712-annual-report-integrated-guidelines_en.pdf [17.8.2009].
} 
Scheme No. 2. - Resources distribution of the Globalization Fund

\begin{tabular}{|l|r|r|r|r|r|r|}
\hline & 2007 & 2008 & 2009 & 2010 & 2011 & 2012 \\
\hline DKK millon 2007 (2007 prices) total & 2000 & 4000 & 6000 & 8000 & 9000 & 10000 \\
\hline Research and development & 1000 & 2000 & 3300 & 4600 & 4900 & 5200 \\
\hline Innovation and enterpreneurship & 350 & 400 & 400 & 500 & 500 & 500 \\
\hline $\begin{array}{l}\text { All young people to have a youth } \\
\text { education }\end{array}$ & 308 & 781 & 1220 & 1702 & 2232 & 2620 \\
\hline Increased tertiary education & 200 & 285 & 537 & 650 & 1147 & 1461 \\
\hline $\begin{array}{l}\text { Strenghtened adult and continuing } \\
\text { education initiative }\end{array}$ & 141 & 534 & 540 & 547 & 217 & 217 \\
\hline
\end{tabular}

Source: NRP Denmark 2007, p. 20

Apart from that, Denmark also supports the demand side of the labour market. It is therefore considered a state where it is easy to run a business. According to the World Bank's Doing Business 2009, Denmark ranked $5^{\text {th }}$ worldwide and $1^{\text {st }}$ in Europe. ${ }^{1}$ It takes only 5 days to start a business and the whole process is free of charge. Similarly to other Scandinavian economies, the business environment is very liberal. According to the Index of economic freedom, ${ }^{2}$ (which covers 10 specific freedoms such as trade freedom, property freedom and investment freedom), in 2009, Denmark ranked $8^{\text {th }}$ worldwide and $2^{\text {nd }}$ in the EU (after Ireland).

In case we summarize the specifics of the Danish economy and labour market features, we should highlight that flexicurity concept is very successful thanks to the particular macroeconomic environment. It is based on special conditions within the Danish economy and the full applicability in other economies is therefore limited.

Based on the public consensus there is a low protection of workers across all of the employers groups which enables to the businesses to react flexibly on situation. Thanks to the their position in the economy, unions bear responsibility for unemployment benefits payments. Their interest is therefore to create such frame within the employability of their members that would be as high as possible. High unemployment means high costs for insurance funds traditionally run by the unions.

Danish policy supports supply and demand side of the labour market. There are highest investments on active labour market policies measures in the EU, high investments into research and development and huge financial resources available for education and entrepreneurship within the Globalisation Fund. Denmark is attractive place to run business. It takes only 5 days to start a business and it is without any charge. The business environment is liberal and trade, investment and other freedoms are widely guaranteed. Before implementing the flexicurity measures into the other economies, we should realize that this concept itself does not have to help substantially without broader reforms of economy being made.

Due to the reasons mentioned below, at the moment it would be quite hard to apply the concept as a whole into the conditions of the Czech economy. Anyway, at the moment the Czechs can choose some of the mechanisms and implement them into their labour

\footnotetext{
${ }^{1}$ http://www.doingbusiness.org/EconomyRankings/ [17.8.2009].

${ }^{2}$ http://www.heritage.org/Index/ [17.8.2009].
} 
market environment. The topic of applicable elements is discussed to a greater detail in the next part of the paper.

\section{Czech labour market and flexicurity}

General labour market background

In the past two decades, the Czech labour market - together with other Central European economies - had to face deep political, social and economic changes in the 1990s and transform the labour markets as well. The labour force was almost overnight confronted with many new requirements (e.g. language knowledge, IT skills, flexibility). According to Nesporova, Cazes (2003) these changes had impact on: ${ }^{1}$

1. Decline in employment rates

2. Shrinking participation rates

3. Growth of unemployment rates (long-term unemployment, unemployment of disadvanced groups, regional unemployment).

All these changes had an impact on labour market performance which weakened significantly at the beginning of the 1990s. It was only after the first economical and labour market reforms had been executed in the 1990s that the Czech economy started to grow. From 2000 to 2008, the GDP grew strongly above the EU average, in 20052008 the annual GDP growth was more than $6 \%$. This had a positive effect on labour market performance. The employment rates were raising and unemployment rates declining. In 2008 the unemployment rate according to the Czech Statistical Office reached the long-term minimum of $4.2 \%$. Nevertheless, due to the impact of the economic crisis the unemployment reached the opposite record $\left(7.9 \%\right.$ in the $2^{\text {nd }}$ quarter of 2009, according to the national methodology) within 7 months and is expected to grow further. In the table Nr. 2, we can see the latest available data demonstrating recent labour market situation in the Czech Republic and in Central Europe. The figures are compared to the Danish labour market.

In case we focus on performaace of the Central European region, we can state that in 2008, the whole region had lower employment rates. The difference between the employment rate in the Czech Republic and Denmark was $12 \%$, in other CE states the difference was even greater.

Table No. 2 Labour market indicators in \% - Central Europe vs. Denmark, 2008

\begin{tabular}{|l|c|c|c|c|c|c|}
\hline & $\begin{array}{c}\text { Employ- } \\
\text { ment rate }\end{array}$ & $\begin{array}{c}\text { Unempl. rate } \\
06 / 09\end{array}$ & $\begin{array}{c}\text { Long-term } \\
\text { unemploymen } \\
\text { t/ total unem. }\end{array}$ & $\begin{array}{c}\text { Part-time } \\
\text { empl/total } \\
\text { employment }\end{array}$ & $\begin{array}{c}\text { Social } \\
\text { expenditure } \\
\text { s/GDP (06) }\end{array}$ & $\begin{array}{c}\text { GDP/ head } \\
\text { EU27=100 }\end{array}$ \\
\hline CR & 66.6 & 6.3 & 50.2 & 3.5 & 18.7 & 80.4 \\
\hline Hungary & 56.7 & 10.3 & 47.6 & 3.1 & 22.3 & 62.9 \\
\hline Poland & 59.2 & 8.2 & 29.0 & 9.3 & 19.2 & 57.5 \\
\hline Slovakia & 62.3 & 11.7 & 66.1 & 2.7 & 15.9 & 71.9 \\
\hline Denmark & 78.4 & 6.2 & 16.1 & 18.0 & 29.1 & 118.3 \\
\hline
\end{tabular}

Source: Eurostat database, OECD, Employment Outlook 2009 - forthcoming edition

${ }^{1}$ Cazes, Nesporová (2003), p. 10-18. 
Furthermore, very essential difference could be found in the category of long-term unemployment rate. These low figures result from the flexicurity model as mentioned above. Denmark has the lowest long-term unemployment thanks to qualification and motivational effects. In the Central European economies, every other person is unemployed for a period longer than 12 months. One year is considered to be a psychological barrier after which the return on labour market gets more complicated.

Another difference can be seen in part-time employment. This is one of the ways to boost employment rates and a way that is favoured mainly by women as it allows them to combine their professional and private lives. Nevertheless, in the Central Europe this kind of employment is not often preferred. Due to the lower economic level tabulated in the last column, the second full-income in the family is very often a necessity to guarantee certain living standard.

The fact that the harmonized data for Danish and Czech unemployment are on the very same level $(6.2 \%$ or $6.3 \%$, respectively) can be considered quite surprising. The unemployment rate in other Central European countries the in $2^{\text {nd }}$ quarter of 2009 was even higher.

Generally, the period of 2005 to 2008 is considered to be a very successful one and until autumn 2008 the labour force demand was very high. First the impact of economic crisis and the slow-down of the economy reflected the real labour market situation with all its weaknesses. In the next part of the paper we will focus on the flexicurity elements which already exist in the Czech Republic and aim on the measures which could further improve the labour market situation.

\section{Flexible labour market}

The difference between employment protections among various groups of workers is the essential problem in this point there. Despite the fact that the overall strictness in 2008 reached 2.1 (OECD average is 2.0), there is a significant difference between protection of regular and temporary workers. As mentioned above in the table No. 1, the EPL index for regular workers is 3.0 and for temporary only 0.9. Furthermore, about only $9 \%$ of regular workers has a contract for a fixed period of time. ${ }^{1}$ This means that there are two groups of workers and two different labour markets on the Czech labour market. The first group is generously protected by quite complicated rules for firing the workers, in the other group the employment protection is very weak compared to the international standards.

Such a high employment protection of most of the workers has a negative effect on employment; the companies are afraid of hiring the workers on regular contracts and prefer other forms of employment, e.g. temporary employment or short-term agreements. It is mainly young workers, who entered the labour market recently and the workers with low achieved education, who are contracted on the basis of these forms of employment. These groups of workers are mainly threatened by unemployment. According to the Czech Statistical Office the unemployment rate of the workers with primary education in 2009 was about $19 \% .^{2}$ In case the employment protection is too

\footnotetext{
${ }^{1}$ Nekolová (2008), p. 27.

${ }^{2}$ http://www.czso.cz/csu/csu.nsf/informace/czam080409.doc [18.8.2009].
} 
high, the effect on this group is negative. Companies prefer not to hire these workers and as a result, those workers often aim into the grey economy or work semi-legally. Here we can see the link with construction of social benefit system.

Broader use of part-time jobs is another feature which could stimulate flexibility of labour markets. As mentioned in the first part, historically, this kind of jobs is very rarely offered in the Czech Republic, the general interest for this type of jobs is lower than in the EU-15. It is due to lower income level that in many cases another full income to the family is required. Concerning female employment, it is usual that mothers with children have a full-time job. Yet in the EU-15 many women with children work part-time. This difference reduces the figures for part-time jobs in the Czech Republic. Despite a rather additional character of the part-time jobs, they can further boost the employment of mothers on maternity leave, students or retired people in case of incentives to the companies.

\section{Generous welfare system}

Before focusing on the topic of welfare system, we should mention the structure of the unemployed according to the highest education achieved. In the $1^{\text {st }}$ quarter of 2009 , the unemployment rate of those with primary education was $19 \%$, in the groups of workers with secondary education it was $4.4 \%$ and for people with tertiary education only $1.6 \%$. Among the long-term unemployed, people with primary education represent $41 \%$, another $44 \%$ are people with secondary education without graduation. The group of those unemployed for a long time in this $1^{\text {st }}$ quarter of 2009 comprised of almost 105 thousand people, 30 thousand of them did not work for longer than 8 years. ${ }^{1}$ Because the wages tend to rise with the achieved education, it is obvious that workers with primary education, who have predominantly low-income, belong into the group most threatened by long-term unemployment.

Another topic which still has not been sucessfully solved in the Czech Republic is the rules for being provided the unemployment benefits. In Denmark, there are strict rules for the unemployed which the unemployed have to fulfil in order to receive unemployment benefits. The possibility to refuse a job during the unemployment period is much more limited than in the Czech Republic, which forces the people to accept the job offered by the labour offices. Furthermore, the legal frame and the existence grey economy in the Czech Republic (creating cca $20 \%$ of the GDP) enables the unemployed to receive the additional financial means. In Denmark, this fact is strictly controlled, which helps reduce this type of unemployment. Last but not least, due to the active labour market measures and the requalification scheme, this group of unemployed people spend much more time in the requalification courses so they do not have spare time to work illegally. To sup up, the current construction of the system enables the low-income and low-educated group of the unemployed to stay outside the official labour market, which boosts the unemployment. Rather ironically, the generosity lies in the lack of factors pushing the unemployed back to the labour market.

The positive fact is that in 2007 , the Czech Republic reformed its social benefit system in such a way to increase the motivation of inactive low-income groups to enter the labour market. The new legal adjustment is giving financial advantage to those welfare

\footnotetext{
${ }^{1}$ http://www.czso.cz/csu/2009edicniplan.nsf/p/3101-09 [18.8.2009].
} 
recipients, who are actively dealing with their situation (e.g. by looking for a job). In case a person asking for welfare benefit does not actively cooperate in looking for a job, rejects a job or does not show own effort to raise his orher income, the amount of the social allowance will be lowered, possibly down to a new category of survival minimum. At the same time, the welfare system was simplified. A number of previous social allowances were replaced by three new allowances: living allowance, exceptional immediate allowance and supplementary allowance. ${ }^{1}$ As a result of this reform dropped since 2006 to 2008 the long-term unemployment rate from $3.9 \%$ to $2.2 \%{ }^{2}$

Despite the reform, there is still a problem with low motivation of the long-term unemployed to enter the labour market. Thanks to the construction of the social system a family with 2 children, one adult who is unemployed on a long-term basis and another economically inactive preson receives about $80 \%$ of the average income of the lowincome group. ${ }^{3}$ To summarize, the low-income and low-educated groups make the biggest share of long-time unemployed due to the still relatively generous social system and high employment protection.

\section{Active LMP}

Active labour market policy is a part of public employment policy. It is executed on the central (Social Security Administration) and on local level (Labour Offices). Within their financial budget, Labour Offices can decide what type of ALPM they will apply according to the need of the local labour market. As mentioned above, this type of labour market policy is relatively new and the amount of means is low - in spite of the continuous growth. In the 1990s, this type of policy was used very rarely. The position of this policy improved and the financial amounts grew since the EU accession. Nevertheless, in 2007 only $0.2 \%$ of GDP aim on ALMP, which means that it is still undersized.

What is further absent is a general consensus about the role of the ALMP. Today, there are two types of ALPM provided by Labour offices - financial incentives to the companies and non-financial incentives, such as qualification courses for the unemployed, consulting etc. The ALMP is financed from the state budget, European Social Fund and Operation Programme (OP) Human Resources Development. According to the Czech National Reform Programme in 2007-13 the OP Human Resources Developement allocates 1.84 billion EUR. ${ }^{4}$

The aim of the ALPM in the Czech Republic is to bring the unemployed back on the labour market - we speak about the so called enforced participation typical for AngloSaxon states. According to Nekolová, ${ }^{5}$ the problem lies in the fact that the groups most threatened by unemployment are not interested in the ALMP measures. According to opinion of the workers of the Labour Offices, there is a pressure from the central level to fulfil formally the Individual Action Plans with this type of unemployed. The

\footnotetext{
${ }^{1} \mathrm{EC}(2007 \mathrm{~b}), \mathrm{p} .22$.

${ }^{2} \mathrm{http}: / /$ epp.eurostat.ec.europa.eu/tgm/table.do?tab=table\&init=1\&plugin=1\&language=en \&pcode $=$ tsisc070.

${ }^{3}$ Nekolová (2008), p. 51.

${ }^{4}$ NRP CZ 2008-10, p. 81.

${ }^{5}$ Nekolová (2008), p. 39.
} 
unemployed can receive further higher social benefits and the effect of the ALPM is only negative and the people on who it is aimed remain unemployed.

Lack of the tradition of further education after completing the formal education is another problem. The intensity of further education and qualification is recorded by the Eurostat with the use of the Life-long learning index. The results of the Czech Republic are not very impressive. In the Czech Republic in 2008, education or training in the four weeks preceding the survey received about $8 \%$ of the workforce compared with almost $30 \%$ in Denmark or $32 \%$ in Sweden. ${ }^{1}$ In the Czech Republic still prevails the feeling that in case the person gets skills and knowledge during education period, he or she can apply them during the whole professional career.

Reasons why further (pre)qualification after completing formal education is low are interesting indeed. According to the questionnaire of the National Training Fund ${ }^{2}$ it is obvious that in case a person is once formally educated, the businesses do not invest in further education due to the high costs $(25 \%)$. About $9 \%$ of businesses still think that only the state is responsible for the education and about $14 \%$ of the workers are not interested.

As we can see, the position of the ALPM is still quite weak, which is caused by the low amount of money invested into this policy and general attitude to the need of investing into human resources. The group of the long-term unemployed, on which the ALMP should be aimed predominantly, is not incorporated into the qualification.

\section{Conclusion}

Danish concept of flexicurity is in general considered for a very successfully thanks to its balance between low employment protection and generous welfare system which stimulates the workers mobility among the jobs. This system is especially beneficiary in case of frictional unemployment when the people are actively seeking the same type of job. The workers unemployed for a longer period are according to this the concept prequalified to facilitate the return on the labour market.

Despite this very positive impression and low long-term unemployment in Denmark we should realize that model functions also thanks to the general economic frame. There are very small differences in protection or various employment groups preventing the creation of dual labour market. Historically, there is a public consensus about low employment protection. Trade unions were and until today still partly are responsible for payment of the unemployment benefits from the insurance funds governed by them. The union's interest was traditionally in creating such conditions on labour market that would minimize the number of unemployed people requiring benefits from their funds.

Danish investments into education and research are strongly above the EU average; the country is one of the most attractive places for running a business worldwide and has a very liberal business environment. In case the flexicurity concept will be implemented into the other economies, we should realize that the success of such an implementation is conditioned by the aspects mentioned above.

\footnotetext{
${ }^{1} \mathrm{http} / / /$ epp.eurostat.ec.europa.eu/tgm/table.do?tab=table\&init=1\&plugin=1\&language=en \&pcode $=$ tsiem080 [16.8.2009].

${ }^{2}$ National Training Fund (2003), p. 92. 
If we apply the golden triangle of flexicurity on the Czech labour markets, we can say that there are a coule of important elements which would help. First of all, the employment protection of the regular workers is (measured by employment protection legislation index) too high, which causes rigidities on the labour market, there is also substantial difference in protection of regular and temporary workers. That dissuades the companies from hiring the workers for shorter period because they would stay in the company also after the time they were needed.

The problem lies in the construction of the welfare system. According to researches, the group most threaten by (long-term) unemployment consists of people with primary education who also belong into the low-income group. In 2009, about $41 \%$ long-term unemployed were the people with primary education; another $44 \%$ with secondary education without graduation. This group suffers from high employment protection because the companies are afraid to hire them as regular workers for shorter periods. Furthermore, the gap between the low-income wages and social benefits is still too small. Despite the reform, a person that is unemployed for a long time, has 2 children and lives with another economically inactive family member receives about $85 \%$ of the average low-income wage. The same group is further not interested in prequalification within the ALMP and the system does not really force them to join such prequalification. Finally we can say that in case the people are not personally interested in getting or receiving a job, the system has actually no financial or non-financial means how to bring them back on labour market. The solution in this case could be to combine lower employment protection with positive taxes to the low-income group to widen the gap between income in employment and unemployment.

Furthermore, in the Czech Republic there is quite a short tradition of prequalification or further education of human resources during their career, which reduces their employability. This corresponds to the value of the Life-long learning index which is below the EU average. Only $8 \%$ of the workforce received education or training in the four weeks preceding the survey in the Czech Republic, which is significantly below Scandinavian countries (30\% in Denmark). To sum up, there is still some space in the Czech Republic to improve dealing with human resources after their completion of formal education to improve the employability of the workforce.

\section{References:}

CAZES, S., NEŠPOROVÁ, A. (2003). Balancing flexibility and security in the Central and Eastern Europe, ILO, Geneva.

Council of European Union. (2008). Integrated Guidelines 2008-10, Bruselles.

Czech Statistical Office, retrieved 16-08-2009 from http://www.czso.cz/csu/ edicniplan.nsf/aktual/ep-3\#31.

Czech Statistical Office, retrieved 16-08-2009 from http://www.czso.cz/csu/csu.nsf/ informace/ czam080409.doc [16.8.2009].

European Commission. (2007a). Flexicurity Pathways, Report by the European Expert Group on Flexicurity. Brusessles. 
European Commission. (2007b). Flexicurity Practices, Brusessles.

European Commission. (2007c), Towards Common Principles of Flexicurity, DG Employment, Luxembourg. ISBN 978-92-79-06477-7.

Eurostat. (2008). Eurostat Yearbook, Europe in Figures. Luxembourg. ISBN 978-9279-06607-8.

MADSEN, P. K. (2002). A Danish model of Flexicurity - A Paradise with some Snakes, Copenhagen: University of Copenhagen.

MADSEN, P. K. (2006). Flexicurity, A new perspective on labour markets and welfare states in Europe, CARMA Research Papers 2006:3, Aalborg: University Aalborg.

MADSEN, P. K. (2007). Distribution of Responsibility for Security and Labour Markets Policy, Country Report: Denmark, WP 07/51, CARMA, Aalborg: University, Aalborg.

National Reform Programme 2008-10 Czech Republic, Retrived 16-08-2009 from http://ec.europa.eu/growthandjobs/national-dimension/member-states-2008-2010reports/index_en.htm

National Reform Programme 2007 Denmark, Retrived 16-08-2009 from http://ec.europa.eu/growthandjobs/national-dimension/member-states-autumn-2007reports/index_en.htm.

National Training Fund (2003), Zpráva o situaci v rozvoji lidských zdroju malých a středních podnikü [Report on situation of human resources development in small and middle enterprises], Prague.

NEKOLOVÁ, M. (2008). Flexicurity - hledání rovnováhy mezi flexibilitou a ochranou trhu práce $v$ České republice, Prague: Research Institute for Labour and Social Affairs. ISBN 978-80-87007-89-1.

OECD. (2007). Education at Glance 2007. Paris. ISBN 978-92-64-0532-0.

OECD. (2008). Employment Outlook 2008. Paris. ISBN 978-92-64-04632-0.

OECD. (2009). Employment Outlook 2009, forthcoming edition. Retrived 16-08-2009 from http://www.oecd.org/document/46/0,3343,en_2649_33927_40401454_1_1_1_37457,00 .html. 


\title{
FLEXICURITY - CHALLENGE TO IMPROVE CZECH LABOUR MARKET
}

Zuzana Potužáková

Metropolitan University Prague, Department of Economics, Dubečská 900/10, 100 31, Prague (potuzakova@mup.cz)

\begin{abstract}
Flexicurity reflects the current basic trend of the EU in guaranteeing high employment levels and attainability of national fiscal systems. It was introduced in Denmark in the 1990s and significantly helped reduce unemployment levels. The Czech labour market, despite the transformation process, has still space for further improvement, especially in the time of economic slow-down. The best way is to try to apply elements and components which have been already successfully implemented in the other EU Member States. The aim of the paper is (based on the statistical indicators and official documents concerning labour markets topic) to describe the basic function of the model and find the components of the flexicurity model which could be used also in the Czech Republic and change labour market operation.
\end{abstract}

Key words: flexicurity, EU, Czech Republic, labour market

JEL Classification: J01, J10, J24

DOI: $10.2478 / \mathrm{v} 10135-009-0005-4$ 